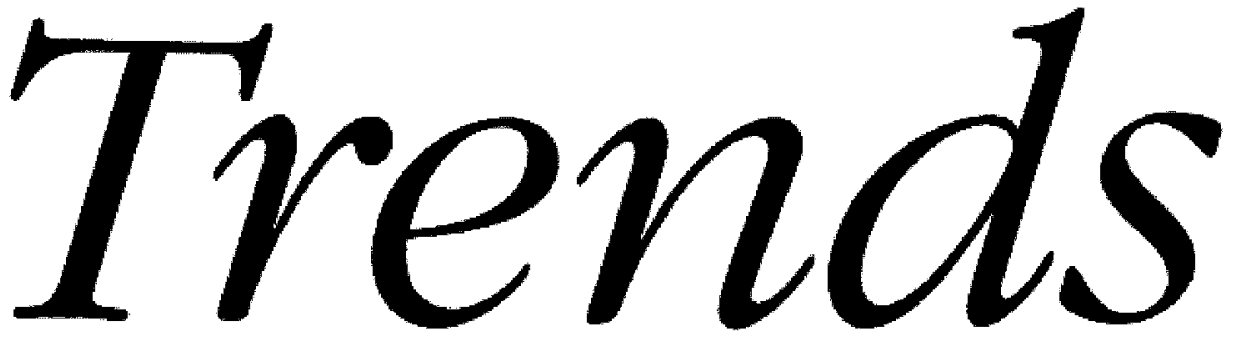

IN LAW LIBRARY MANAGEMENT AND TECHNOLOGY

Edited by Philip C. Betwick ^ For academic, fim, corporate, and government law libratrans

\title{
Who Let the Dog Out? Implementing a Successful Therapy Dog Program in an Academic Law Library
}

$B y$ JuLIAN AIKEN, Access Services Librarian, Lillian Goldman Law Library, Yale Law School \& FEMI CADMus, Associate Law Librarian for Administration, Lillian Goldman Law Library, Yale Law School

\section{Background and the Therapy Animal Concept}

The motivation for introducing a therapy dog to the Yale Law Library was twofold. Inarguably, attending law school can sometimes be stressful. Studies indicate that, particularly in the first year of law school, when newcomers are adjusting to new teaching methods, materials, external and internal expectations, and even geographic locations, students can experience elevated stress levels. ${ }^{.}$The evidence that visits from therapy dogs have resulted in increased happiness, calmness, and overall emotional well-being was a strong factor in proposing the introduction of Monty, the therapy dog, to the stacks: the health and general happiness of the students in our school is of paramount importance to the Yale Law School and Library. ${ }^{2}$ 


\section{Trends}

The concept of therapy animals providing psychological and physiological benefits to humans is almost as old as mankind itself. Around the classical temple of Epidaurus tablets were found testifying to the local belief in the miraculous cures to be wrought there by the temple dogs. ${ }^{3}$ More recently, serious scientific investigations of the benefits of therapy animals have taken place. In 200I, a study of stockbrokers suffering from hypertension concluded that exposure to therapy dogs was more effective than prescribed medications in blunting blood pressure responses to mental stress. ${ }^{4}$

Another area of great importance to the Library is, of course, our ongoing efforts to meet the needs and support the broader interests of our user population, to remain relevant in an era in which collections are increasingly electronic and in which, indeed, a J.D. can be obtained entirely online. In a 2008 conversation about the future of law libraries, Blair Kauffman, Director of the Yale Law Library, discussed the law library in terms of "what architects call a 'third place'where your home is your first place, an office or a classtoom is a second place, and social places, like dining halls and lounges and coffee shops and bookstores and libraries are a third place. The library is a third place that speaks to individual study and research. It's the one thing that really distinguishes residential education from other types of education ... the library is what holds the students to the law school." 5

There is existing evidence attesting to the fact that libraries which spend time focusing upon becoming more welcoming and attractive to students enjoy increased usage. 6 the Yale Law Library a good deal of creative thinking is encouraged, in an effort to provide creative, non-traditional services to our patrons. The library lends, for example, bicycles, soccer balls and goals, phone chargers, umbrellas, iPads, DVDs and popular fiction, in addition to the customary print legal materials. These services have all been greeted positively by Yale law students. 


\section{Implementing the Pilot Project}

It was not difficult to convince library administration and staff about implementing a therapy dog program during stressful periods, such as exams. In fact, when our access services librarian came up with the idea, everyone in the library was uniformly enthusiastic, especially since he personally owned the therapy dog to be used, eliminating the need to look to outside agencies for therapy dogs. Monty had been certified in the United Kingdom and had to go through a certification process in the United States under the auspices of the Delta Society. This proved to be the easy part; what would prove more difficult was navigating existing university policies and practices relating to animals in the workplace and confronting the perception that this was an unserious idea.

Our first major roadblock was a human resources policy (restated by the university's office of environmental health and safety) which in essence precluded the presence of pets in the workplace for health, safety, and courtesy reasons. ${ }^{7} \mathrm{We}$ requested a review of our particular situation, contending that a library therapy dog should be excluded from this policy because it was not a pet but a trained, certified animal, akin to a service animal. While therapy animals have not been legally defined under federal law (unlike service dogs within the context of the American Disabilities Act), some states have laws defining therapy dogs. In New York for example, a therapy dog "means any dog that is trained to aid the emotional and physical health of patients in hospitals, nursing homes, retirement homes and other settings and is actually used for such purpose, or any dog owned by a recognized training center located within the state during the period such dog is being trained or bred for such purpose."

Our request for a review was forwarded to a special committee in the human resources department, and after extended deliberation we received tentative approval to initiate a pilot program. Approval was tentative pending further review by the university's office of general counsel and law school administration. As part of this review, Monty's owner had to sign an indemnity agreement taking 


\section{Trends}

full responsibility for the behavior and actions of the dog. Law school administration also signaled final approval of the pilot project, but we still had to contend with perception issues about the seriousness of the program. It was helpful to be able to point to other successful therapy dog programs already existing and successfully implemented in a few universities and public libraries across the country. In essence this was not a novel idea, although it would be considered novel to academic law libraries as we were unaware of any existing programs in the United States or elsewhere.

\section{Feedback and Results of the Pilot Project}

The three-day therapy dog pilot program, initiated in the spring semester of 2011 , was very successful. A total of 27 half-hour sessions were scheduled and student interest was extremely high. In fact, interest was so high that at the end of the pilot we had 84 student visits, with another 29 students waitlisted. Students visited with Monty, the therapy dog, in groups of three to four per session in a private and secluded location in the library (the access services librarian's office). Initially Monty's owner and handler, our access services librarian, worked at a cubicle near his office but soon moved back into his office as this seemed to help Monty get more comfortable and acquainted with his new environment. The presence of a library staff member did not inhibit student interaction with Monty and actually helped with observing the ongoing interactions and obtaining direct feedback from the students.

Feedback from students was overwhelmingly positive and one student commented: "I have to say that I left my session today completely calm and with a big smile on my face. That is definitely not my typical state of being when I'm at school, and it was an incredibly refreshing change from the status quo."

We forwarded a report to university and law school administrators providing student feedback and observations, as well as recommendations for moving forward if the program were to become permanent. One of our recommendations was a reduction in the number of sessions to avert owner and dog fatigue. We also had several requests from students to expand visits beyond the private dedicated 
space in the library to outside space like the courtyard. Initially the library was only able to obtain permission to host the program inside of the library in a private secluded space to protect patrons with dog phobias or allergies. Since Monty is hypoallergenic, allergy issues never came into play.

In the end we received the necessary approval to continue with the program on a permanent basis during stressful periods like exams. We tweaked the program by reducing the sessions but did not receive permission to extend it beyond the confines of the library to the courtyard as requested by many students (maybe this will be granted in the future).

\section{Conclusion}

The provision of a therapy dog was considered a very natural extension of the library's innovative and positive approach to its users. Implementing a library therapy dog program has created yet another avenue for the library to interact directly with students, cultivate face time, and solidify our traditional role as librarians while providing a pioneering service which students have embraced as invaluable. While it exacts a substantial investment of time and resources, if carefully planned out it yields excellent results in terms of solidifying relationships with one most important library patron base-students.

\section{Notes}

I. Suzanne C. Segerstrom, Perceptions of Stress and Control in the First Semester of Law School, 32 Willamette L. Rev. 593 (1996).

2. James A. Serpell, Animal Companions and Human Well-Being: An Historical Exploration of the Value of Hunnan-Animal Relationships, in HANDBOOK ON ANIMALASSISTED THERAPY: THEORETICAL FOUNDATIONS AND GUIDELINES FOR PRACTICE 3 (Aubrey H. Fine ed., 2000).

3. Linda M. Hines, Historical Petspectives on the Human-Animal Bond, 47 Am. Behav. Scientist 7 (2003).

4. Karen Allen, Barbara E. Shykoff \& Joseph L. Izzo, Jr., Pet Ownership, but Not ACE Inhibitor Therapy, Blunts Home Blood Pressure Responses to Mental Stress, 38 Hypertension 8I5 (200I). 


\section{Trends}

5. Richard A. Danner, S. Blair Kauffman \& John G. Palfrey, The Twenty-First Century Law Library, IOI Law Libr. J. I43 (2009).

6. Id.

7. For a review of public accommodation access rules relating to therapy animals, see John Ensminger \& Frances Breitkopf, Evolving Functions of Service and Therapy Animals and the Implications for Public Accommodation Access Rules, 6 I. Animal L. I (2010).

8. N.Y. Agric. \& Mkts. Law $§ I 08(26)$ (20II).

Julian Aiken, Access Services libratian, Lillian Goldman Law Libraty, Lillian Goldman Law Library, Yale Law School, New Haven, Connecticut.Email:<julian.aiken@yale.edu>. Feni Cadnus, Associate Law Libratian for Administration of the Lillian Goldnan Law Library, YaleLawSchool.New Haven,Connecticut.Email:<femi.cadmus@yale.edu>

Trends is published by William S. Hein \& Co., Inc. I285 Main St. / Buffalo, NY I4209 Phone: (800) 828-7571; (716) 882-2600 Fax: (716) 883-8100

Email:mail@wshein.com

ISSN 0893-6773

The complete collection of articles published in Trends is available in HeinOnline (http://heinonline.org)
Editor: Philip C. Berwick, Associate Dean for Information Resources

Washington University School of Law

Law Library

Campus Box I I7 I

St. Louis, MO 63130

Phone: (3I 4) 935-4042; Fax: (3I4) 935-7I25

Email: <BERWICK@WULAW.WUSTL.EDU>

(C) 2011 by William S. Hein \& Co., Inc. 